\title{
Women's Economic Empowerment: An Integrative Review of Its Antecedents and Consequences
}

\author{
Kumari DAT \\ Department of Banking and Finance, Waymaba University of Sri Lanka
}

\begin{abstract}
The World Bank defines women's empowerment as a criterion for sustainable development and for the fulfilment of the Millennium Development Goals (MDG). Economic empowerment has been identified as a main fragment of women's empowerment in literature. Women's economic empowerment would lead to an expansion of women's labour force in order to participate as an important factor for inclusive growth of the country. Economic empowerment directly influences the improvement of women's decision-making power and their financial well-being. The main purpose of this paper is to provide an integrative review of antecedents and consequences of Women's Economic Empowerment. A comprehensive review of women's economic empowerment is presenting as an important topic for the policy makers and future researches. An integrative framework and a detailed summary table are provided based on the previous literature. Based on the findings, five main determinants of women's economic empowerment were identified namely, Decision making power, Controlling over the use of income and expenditure, Leadership in the community, Control over the time allocation and Financial wellbeing. Among the total consequences an inclusive growth revealed as main consequence. The compendium of antecedents and consequences of women's economic empowerment can be used by policy makers for their policy decisions as to identify the most significant antecedent to improve economic empowerment and to formulate new economic strategies to achieve an inclusive growth as a main consequence of women's economic empowerment. As new vistas emerge for furthering economic empowerment leading to inclusive growth, this paper provides a timely review and an integrative framework of existing research on women's economic empowerment and, its antecedents and consequences. This paper contributes to the economics discipline both by integrating a wide body of research on an important economics topic and by offering broad avenues for further research.
\end{abstract}

Keywords: Women's Economic Empowerment, Decision making power, Controlling over the use of income and expenditure, Leadership in the community, Control over the time allocation and Financial wellbeing.

DOI: $10.7176 / \mathrm{JPID} / 56-05$

Publication date: November $30^{\text {th }} 2020$

\section{Introduction}

Although a universal definition for the term "women's economic empowerment” is unavailable, many reputed international organizations have attempted to define and explain it on their own. The Organization for Economic Co-operation and Development (OECD) in 2015, defines it as, "women's economic empowerment is the capacity of women to participate in, contribute to and benefit from growth processes in a way that recognizes the value of their contributions, respect their dignity and make it possible to negotiate a fairer distribution of the benefits of growth". The OECD also elaborates the positive impact that the economic empowerment has upon women's accessibility to opportunities and economic resources such as financial services, employment opportunities, skills development, market information and various other productive assets. The World Bank defines women's empowerment as a criterion for sustainable development and for the fulfilment of the Millennium Development Goals (MDG). The fact that the upturn of female employment would lead to an expansion of women's labour force engagement is quite undeniable. This is directly proportional to the improvement of their personal revenue and the economic growth. Consequently, there emerges a need to manage their incomes, savings and investment. Although this need may be opportunely fulfilled by attaining the financial market so as to achieve the financial wellbeing, which leads to economic empowerment. The financial wellbeing helps to increase investments and creating more employment opportunities which induced to reducing poverty and inequalities. Therefore, women's economic empowerment facilitates to increase propensity to savings, accumulating investment and financial wellbeing paved the way for inclusive growth

\section{Definitions of Women's economic empowerment}

The word 'empowerment' is believed to have emerged from the Spanish word empoderaminto which was adopted in a project for financing women with the purpose of empowering them. In the view of Serageldin, (1991), "the idea of empowerment manifests all levels of societal interaction which allow weak and marginalized groups to have access to tools and materials for their own destinies". However, Olawaye, (1996) emphasis that empowerment is a concept that has become popular in recent times to describe an enabling process of the socially marginalized persons and groups to gain advantage and opportunities otherwise non-available to them. 
Further Udegbe (1996) emphasizes that "empowerment acquires adequate knowledge, capacity confidence and idea to decide what is good for person(s) and the same encourage them willing to function accordingly".

The concept of empowerment also incorporates a thought of empowering people either in the form of individual or group who has been facing the challenges of social and economic deprivation (Kabeer, 2001). In other words, the term 'empowerment' creates a sort of entrepreneurship or encouragement among the poor sections of the society who are physically and mentally willing to do certain activities in promotion of their lives but hierarchy, which is inbuilt in social system, prevents them to do so because of their poor socio-economic background (Haque \& Zulfiqar, 2015). Accordingly, empowerment generates power among poor communities of the society. In the perspective of social sciences, the term 'empowerment' could be defined as the process of making people self-sufficient in all spheres of life such as social, religious, cultural, political, and economic for the betterment of their lives (Malhotra et al., 2002). In Gandhi's view, empowerment is a power, which enables people to act outside of their house to the immense pride. As per the definitions discussed in this section, the word empowerment is much suitable in the context of poor and vulnerable sections of society because it creates expansion of assets and capability of individual or group to promote participation, make negotiation, control over non-cooperative atmosphere, and generate influence and accountability towards the institutions, which promotes their lives. Therefore, empowerment is the process of self-strength, self-reliance and self-power which promote the dignity of the individual within the group or society (Krishna, 2003) and makes persons efficient in the process of making fast decision and encourages them to protect their rights.

Empowerment became a popular term when women were speaking about gaining control over their lives and participating into the decisions that affect them in the home, community, governance and international development policies (Hallward-Driemeier, 2011). According to Khandker, (1998) women empowerment can be viewed as the component of several inter-related and mutually reinforcing component. Making headway in alleviating poverty and promoting equitable growth is inextricably linked to improving women's lives and increasing their participation in decision making (Allsopp \& Tallontire (2014). Some researchers (e.g. Haque, \& Zulfiqar, 2015) argue that women's empowerment helps raise economic productivity and reduce infant mortality and it contributes to improved health and nutrition. Therefore, women empowerment is one of the recent priority issues in developing countries, since women have less salaried jobs. According to Mayoux (1998) empowerment is a multidimensional and intertwined method of change in relating to power. Krishna (2003) stated that women's empowerment is a process through which women can make their choices and renovate these choices into desired actions and outcomes.

Empowerment has been discussed by most of researchers (e.g. Paulino et al., 2016) in terms of economic perspective. Economically empowering women is indispensable both to apprehend women's rights and to achieve broader development goals such as economic growth, poverty reduction, and social welfare. According to Golla et al., (2011), when women have the ability to succeed and advance economically as well as have the power to make economic decisions, women are said to be economically empowered. Many researchers and scholars (e.g. Goldman and Little, 2014) argue that women's economic empowerment promotes inclusive growth in many developing countries. Some researchers (Khandker, \& Cartwright, 2006) shows that a large portion of the hard-core poor are the women, because they face social barriers in accessing formal finance such as savings and credits that make it is much harder for them to overcome poverty and they are more susceptible to becoming poor when they lose the male earning member of the family due to abandonment, divorce or death. Further Siddik (2017), pointed out continued disparities between women and men in employment and income opportunities, education, financial literacy and control over assets demonstrate that development activities are centered on the men.

On the other hand, women's economic empowerment is vital to recognize women's right (Handa \& Davis, 2006). Economy and organizations start to realize that women empowerment is a win-win situation not only for women but also for economy as a whole (Rawlings \& Rubio, 2005). Further Hoddinott, \& Alderman, (1997) argue that economically empowered women are able to enjoy wellbeing and also help in increasing productivity, economic growth, reducing poverty and enhancing efficiency. Therefore, empowerment of women promotes sustainable development of a community (Thomas, 1990) as sustainability develops and determines, based on equilibrium structure of society, a society that does not make discrimination or is biased against any social group or gender (Fletschner, 2008). Further, sustainable social structure comprises social and economic empowerment, financial literacy and financial freedom of women to free access to the formal financial system (Khandker, \& Cartwright, 2006). These factors promote their active involvement in development of their own, society and whole nation (Thomas, 1990). Women being the major proportions of society get chance in all spheres of life and definitely become the part of sustainable development (Fletschner, 2008). According to Kabeer, (2001), as women held responsibilities of many facets of family structure, empowering women means empowering whole family, because women serve families on various aspects, which fall under the category of human resources development. Mayoux, (1997) noted that women by sitting idle at home even watch the progress of the activity of the family members and interfere in the matter to promote their career. 
According to above discussion, women economic right is definitely an important indicator for enhancement of their status. Therefore, women's financial knowledge should be accessed in terms of financial literacy by educating more employment avenues and financial awareness etc. it would all lead to the women economic freedom (Hulme \& Mosley, 1996). This dimension covers strength of financial decision making benefit of economic growth, financial access, credit, social cohesion, local participation and interaction of formal financial transactions, etc., for betterment of their lives (Mayoux, 1997). In this regard, developing countries give priority financial literacy for more for financial inclusion to improve the economic empowerment of their women. However, in the new global economy, women's empowerment has become a central issue for countries to be able to achieve development goals such as economic growth, poverty reduction, health, education and welfare (Golla et al., 2011; Maheswari, \& Revathy,2016; Das, 2016; Kumari \& Subrahmanyam, 2017; Roy and Jain 2018; Angela, John \& Ting, 2019). Therefore, most of researchers developed the interest to investigate the relationship between women's economic empowerment, financial inclusion and financial literacy. As the women empowerment has been analyzed by previous researchers in different perspectives, some definitions have been summerised into table 1 . for getting clear picture about the concept for present study.

Table 1: Defining women's economic empowerment

\begin{tabular}{|c|c|}
\hline Source & Conceptual definitions \\
\hline Kabeer (2001) & $\begin{array}{l}\text { The expansion of people's ability to make strategic life choices, within their households and } \\
\text { their communities, particularly in contexts where this ability has been limited. }\end{array}$ \\
\hline Malhotra (2002) & The ability of people to make strategic choices in areas that affect their lives. \\
\hline Krishna (2003) & $\begin{array}{l}\text { Women's empowerment is a process through which women can make their choices and } \\
\text { renovate these choices into desired actions and outcomes. }\end{array}$ \\
\hline Kabeer,(2005) & $\begin{array}{l}\text { Individual's or group's capacity to make choices and transform those choices into desired } \\
\text { actions and outcomes. }\end{array}$ \\
\hline $\begin{array}{l}\text { Malhotra and } \\
\text { Mehra (2011). }\end{array}$ & $\begin{array}{l}\text { Women's economic empowerment is fast becoming a key instrument in promoting their } \\
\text { abilities to achieve their rights and well-being which subsequently reduces household } \\
\text { poverty and increases economic growth, productivity and efficiency. }\end{array}$ \\
\hline $\begin{array}{l}\text { Golla et al., } \\
(2011)\end{array}$ & $\begin{array}{l}\text { A woman is economically empowered when she has both the ability to succeed and advance } \\
\text { economically and the power to make and act on economic decisions. To succeed and } \\
\text { advance economically, women need the skills and resources to compete in markets, as well } \\
\text { as fair and equal access to economic institutions. To have the power and agency to benefit } \\
\text { from economic activities, women need to have the ability to make and act on decisions and } \\
\text { control resources and profits. }\end{array}$ \\
\hline DFID (2012) & $\begin{array}{l}\text { "Economic empowerment is a process that increases people's access to and control over } \\
\text { economic resources and opportunities including jobs, financial services, property and other } \\
\text { productive assets (from which one can generate an income), skills development and market } \\
\text { information" }\end{array}$ \\
\hline $\begin{array}{l}\text { Goldman and } \\
\text { Little, (2014) }\end{array}$ & $\begin{array}{l}\text { Empowerment is a continuous, phased and relational process that occurs across scales and } \\
\text { pathways }\end{array}$ \\
\hline $\begin{array}{l}\text { Allsopp and } \\
\text { Tallontire, (2014) }\end{array}$ & $\begin{array}{l}\text { The empowerment was defined as a dynamic process that follows a series of sequential } \\
\text { steps in which ownership of one type of power increases the likelihood and the ability to } \\
\text { exercise other forms of power thus creating a positive 'power spiral' }\end{array}$ \\
\hline $\begin{array}{l}\text { Haque and } \\
\text { Zulfiqar }(2015)\end{array}$ & $\begin{array}{l}\text { Economic empowerment is a combination of individual's knowledge, ability, skills and } \\
\text { confidence for handling her own financial wellbeing. }\end{array}$ \\
\hline $\begin{array}{l}\text { Gilabert, Dietz \& } \\
\text { Grabs (2016) }\end{array}$ & $\begin{array}{l}\text { A woman is economically empowered when she has both the ability to succeed and advance } \\
\text { economically and the power to make and act on economic decisions. }\end{array}$ \\
\hline $\begin{array}{l}\text { Haque \& Zulfiqar } \\
(2016)\end{array}$ & $\begin{array}{l}\text { Economic empowerment is a combination of individual's knowledge, ability, skills and } \\
\text { confidence for handling her own financial wellbeing. }\end{array}$ \\
\hline $\begin{array}{l}\text { Mathews \& } \\
\text { Nandhini (2016) }\end{array}$ & $\begin{array}{l}\text { Women's economic empowerment, which entails that women have the authority to make } \\
\text { their own decisions regarding use of their resources, leads to prosperity for families and } \\
\text { communities. }\end{array}$ \\
\hline OECD (2018) & $\begin{array}{l}\text { Economic empowerment is the capacity of women to participate in, contribute to and } \\
\text { benefit from growth process in ways that recognise the value of their contributions, respect } \\
\text { their dignity and make it possible to negotiate a fairer distribution of the benefits of growth. }\end{array}$ \\
\hline $\begin{array}{l}\text { Vithanagama } \\
(2018)\end{array}$ & $\begin{array}{l}\text { To succeed and advance economically, women need the skills and resources to compete in } \\
\text { markets, as well as fair and equal access to economic institutions. To have the power and } \\
\text { agency to benefit from economic activities, women need to have the ability to make and act } \\
\text { on decisions and control resources and profits. }\end{array}$ \\
\hline
\end{tabular}

Source: Author constructed based on the literature 


\section{Theoretical models of women's economic empowerment}

Kabeer's Three Dimensional Model

Trans Theoretical Model(TTM) (also called the Stages of Change Model), developed by James Prochaska \& Carlo DiClemente (1984); Prochaska, DiClemente, \& Norcross (1992); Prochaska \& Velicer (1994), was derived by studying human experiences and combining existing psychotherapy models. Further TTM was designed to help people intentionally change behavior by understanding process of changed. However, based on the main principles of TTM, three dimensional model was developed by Naila Kabeer in 1999. This model can be applied for conceptualize woman empowerment. According to Kabeer's framework empowerment is a dynamic process, in which women acquire resources that enable them to develop voice and the capacity to articulate preferences. It will be provided the capacity to make decisions to fulfill their own aspirations. According to Kabeer (2005) three dimensions of empowerment can be adopted to explain the pathways through which empowerment occurs. (See figure 1)

Figure 1. Theoretical model of women's empowerment

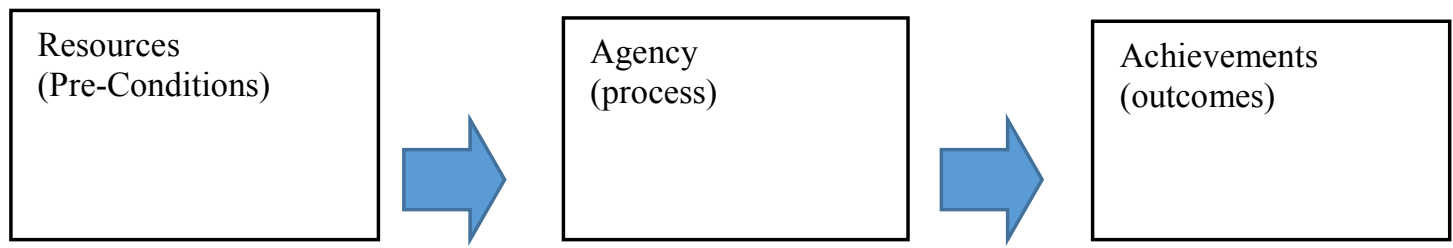

Source: Naila Kabeer (1999)

In this model, the resources include material, human or social in form such as schooling attainment, skill development, and self-efficacy; social resources such as participation in organizations, access to peer networks, and access to role models outside the family; and economic resources or material assets such as earnings, property, and land (Huis et. al, 2017). Resources enable but do not necessarily guarantee empowerment because of the broader structural and normative environment in which girls grow up (Hansen, 2015). From a theoretical point of view, a women's ability to become empowered at the individual level depends on the environment in which she lives (e.g., Pitt et al., 2006). The second dimension is agency which provides access to resources as a necessary pre - condition of empowerment (Kabeer, 1999). However, if women are living in a much disempowered community, it will be difficult for her to gain access to the resources to develop voice and agency (e.g., Kabeer, 1999; Grabe, 2012). And lastly, the third dimension is achievements, which refers to the consequences of the choices made (Kabeer, 1999). According to Kabeer (2005), change in one dimension can lead to changes in the other dimensions.

Based on the Kabeer (2005) three dimensions, Kumari (2020), has built a new model for women's economic empowerment. In the model, women's economic empowerment Centrals by the two main variables named as financial literacy and financial inclusion. By using the Kabeer's three dimensions' process kumara (2020) attempted to reconstruct the model in her PhD thesis 2020. Accordingly, the model was rearranged as depicted in figure 2. Figure.

Figure 2: Conceptual model for women's Economic Empowerment

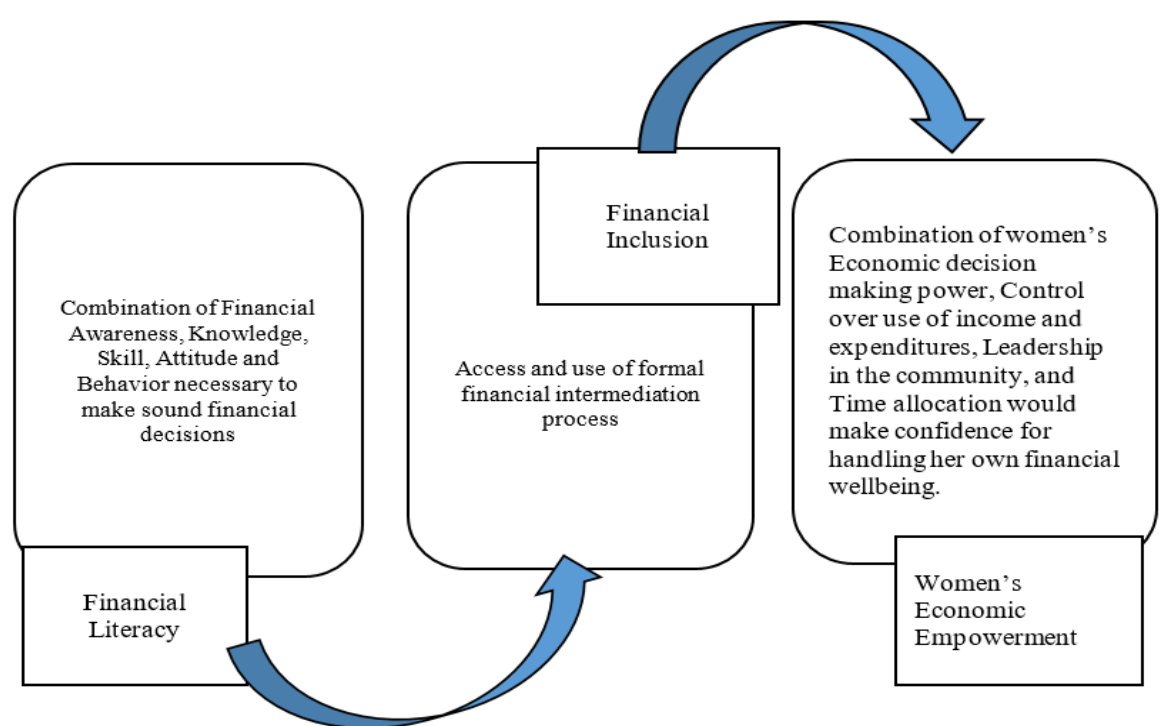

Source: Kumari (2020a) 


\section{Determinants of women's economic empowerment}

According to Haque, \& Zulfiqar (2016), when women have the ability to succeed and advance economically as well as have the power to make economic decisions, women are said to be economically empowered. Further, Vithanagama R. (2016a) argue that economically empowered women are able to enjoy financial wellbeing and also help in increasing productivity, economic growth, reducing poverty and enhancing efficiency. Further Maheswari, \& Revathy, (2016), pointed out continued disparities between women and men in employment and income opportunities, education, financial literacy and control over assets demonstrate that development activities are centered on the men. Empowerment has been discussed by most of the researchers (e.g. Haque, \& Zulfiqar (2016) in terms of economic perspective. Economically empowering women is indispensable both to apprehend women's rights and to achieve broader development goals such as economic growth, poverty reduction, and social welfare. According to previous researchers (Arora, 2016), women's economic empowerment is influenced by many factors. However, Bonga et al., (2016) noted that financial literacy become very prominent in the modern society. Financial literacy facilitates the growth and the molding of finances in an appropriate manner. Accordingly, it supports to achieve economic wellbeing in the rural communities (Devi, 2016; Batra, 2013). Well informed financial decision making is turning into a requirement for economic empowerment of women as a result of constant shifting in the financial market and the intensification of individual responsibility (Lusardi, 2017). While reviewing previous literature in the purpose of identifying the antecedents of women's economic empowerment, researcher did meta-analysis and selected determinants which were commonly used in the previous studies. Accordingly, there were five main determinants identified.

\subsection{Decision making power}

Decision-making power is the ability to influence decisions that affect one's life - both private and public (Deka, 2015). Formal access to positions of authority and to this processes is an important, if insufficient, condition for women to have decision making power in the public domain (Adam, et al., 2018; Islam, 2014). Decision-making power is a composite of access, capabilities and actions that shape whether women have influence the society or their private life. While considering, economic empowerment, the decision making power consider under the financial point of view (Deka ,2015; Karunathilake, 2016). Therefore, in the research context, the decision making power referred as, to the power of poor rural women to make household economic decisions for achieving short and long term economic wellbeing in their households Arora, 2016; Maheswari, 2016; Haque et al., 2016; Bonga et al., 2016; Singh et al.,2017; Lusardi et al., 2017; Roy et al 2018).

\subsection{Control over the use of income and expenditures}

The next important issue is controlling over the use of income and expenditure. Without this step, will be spending money out of track. To control the income and expenditure, it is best to directly prepare the detailed document to controlling an income and expenditure, while developing the budget Alkire, et al., 2012; Biswas, 1999; Malhotra et al., 2002; Deka, 2015. The household budget should be communicated with all the relevant staff. Under the women's economic empowerment, controlling power of the income and expenditure of family members as well as controlling herself is an important phenomenon of her empowerment (Deka ,2015; Gilabert, Dietz, \& Grabs, 2016; Soni, et al., 2016. Deka ,2015; Gilabert, Dietz, and Grabs ,2016). Therefore, in the research context, controlling the use of income and expenditure termed as; authority and willingness of poor rural women to control the over expenditure of their families with the purpose of using this resources to productive ways. Karunathilake, 2016; Arora, 2016; Maheswari, 2016; Haque et al., 2016; Bonga et al., 2016; Lusardi et al., 2017; Singh et al.,2017; Kumari,2017).

\subsection{Leadership in the community}

Women have long been the mainstay of communities and are heavily involved in community initiatives in various forms. Though often the unrewarded heroes of community action, women's role in community development has become important (Dietz, \& Grabs ,2016; Alkire, et al., 2012; Deka ,2015). Especially, in some communities like rural poor, they have established themselves as leaders in community development and acquired the skills that have brought positive change to their communities. Women leaders play key roles in establishing and maintaining important relationships and networks in their communities (Gilabert, Gilabert, Dietz, and Grabs ,2016; Karunathilake, 2016). They face cultural, economics, and social barriers in leading the community and in many cases overcoming those barriers become their motivation. While their comprehensive approach has influenced the evolution and nature of community development, women's contributions have been neither widely acknowledging nor explicitly credited. The results of this study provide deeper insights into women's thinking about leadership and community development (Arora, 2016; Maheswari, 2016; Haque et al., 2018; Bonga et al., 2016; Singh et al.,2017; Lusardi et al., 2017; Kumari, 2019. Therefore, according to the research context, leadership in the community means the extent to which poor rural women can influence the common decisions of community and degree of other community people willing to accept their views Roy et al., 
2018; Vithanagama, 2018).

\subsection{Control over the time allocation}

A study by Hoque and Itohara (2009) reported time allocation is contributing to an extent in planing family activities and participation in family leisure time based on the decision making power of the rural women. And also stated that time spending programme among family members is developing leadership of the rural women (Arora, 2016; Maheswari, 2016; Haque et al., 2016.This study was conceptualized considering basically five important dimensions of women's economic empowerment that identifies five principles in which empowerment are achieved including control over the time allocation as an important dimention (Swamy,2014; Deka ,2015; Gilabert, Dietz, and Grabs ,2016; Karunathilake, 2016; Kumari, 2017). Therefore, according to the research context, control over the time allocation means ability and willingness of poor rural women for allocating their time for different tasks and ability to decide their leisure time in between their day to-day work schedule (Bonga et al., 2016; Singh et al.,2017; Lusardi et al., 2017; Roy et al 2018. Another sub-dimention of the study is financial wellbeing, attributing to some extent in generating economic empowerment and participation in financial decision making power of the rural women (Dash, Prasad \& Koshy ,2016).

\subsection{Financial wellbeing}

Empowerment is power or authority to someone. Women are important to the family as a mother as well in a society. Women are working in the family without any compensation but in the workplace they earn more money with their high position. Empowerment of women refers to giving decision making power to women in social, economic and financial empowerment of life (Haque, 2016; Gilabert, Dietz, and Grabs ,2016; Karunathilake, 2016; Arora, 2016; Kumari, 2020). Empowerment of women is very much essential to achieve sustainable development. The process of empowerment should start from the home. Women's position in the household determines women's autonomy in the family (Kabeer, 1999; Haque \& Zulfiqar ,2016; Kumari,2017). According to the financial wellbeing, it is worth to examine whether can decide about household matters like buying household assets and managing financial resoureces, having access to bank, have security of financial future, have ability to make choices or have enough assets to do day to day financial transactions (Deka, 2015; Maheswari, 2016; Haque et al., 2016; Bonga et al., 2016). Therefore, according to the research context financial wellbeing refreed as: ability of poor rural women to fully meet current and ongoing financial obligations and feel secure in their financial future, and is able to make choices that allow them to enjoy life. United Nation Foundation ,2015); Biswas ,1999; Krishnan and Silvi,2011; Singh et al.,2017; Lusardi et al., 2017). According to the previous literature, determinants of women's economic empowerment can be explained by reflecting the main five determinants.

\section{Conclusion}

The literature arranges in this paper was mainly focused on the conceptual background of women's economic empowerment in different perspectives. In this process, the author did not pay special attention to one particular economy and general analysis of the respective concepts was carried out. However, this phenomenon is more relevant to developing countries other than developed countries. According to the critical literature review given in this paper, women's economic empowerment becomes the crucial determinant of the economy that are focusing on achieving an inclusive growth of the country. Further, women's economic empowerment is at a low level in developing countries. And different antecedents are being influenced by the level of economic empowerment in those countries. Mainly there were five antecedents identified. However, in general, women's economic empowerment has a direct causal relationship with economic growth. As per the previous literature, consequences of women's economic empowerment named as financial wellbeing, poverty alleviation, creating employment and resulting income equality etc. Policy decision-makers should consider improving the level of women's economic empowerment for achieving economic growth. Further, future researchers can design some empirical studies in different socio-economic contexts for analyzing the contribution of women's economic empowerment on economic growth. Finally, academics can pay special attention to the antecedents of women's economic empowerment and should examine which factors are more contributing to determine the women's economic empowerment.

\section{References}

Adam, A. M., Boadu, M. O., and Frimpong, S. (2018). Does Gender Disparity in Financial Literacy Still Persist After Retirement? Evidence from Ghana. International Journal of Social Economics, 45(1), 18-28. Arora, A. (2016). Assessment of Financial Literacy among working Indian Women, https://www.researchgate.net/publication/298790053, Article March 2016.

Batra, A. (2013). Financial inclusion \& women empowerment: A Myth or Reality, International Journal of Research in Finance \& Marketing,3(12),16-25. 
Bonga, W. G., \& Mlambo, N. (2016) Financial Literacy Improvement Among Women in Developing Nations: A Case for Zimbabwe. Quest Journals, Journal of Research in Business and Management, 4(5), 22-31.

D.A.Thakshila Kumari. (2017), "Financial Literacy: An Essential Tool for Empowerment of Women through Financial Inclusion - Literature Review" Equality and Management, Faculty of Economics and Management, University of Szczecin, Poland.

Debroy, B., \& Khan, A.U. (2005). Integrating the rural poor into markets. New Delhi: Academic Foundation.

Deka, P. P. (2015). Financial literacy and financial inclusion for women empowerment: A study. International Journal of Applied Research, 1(9), 145-148.

Devi, A. (2016). Financial literacy among women: A sample study in the Kamrup district of Assam. EPRA International Journal of Economic and Business Review, 4(2), 144-147.

Ghozali, I. (2014). Structural Equation Modeling: Metode Alternatif Dengan Partial Least Square (Structural Equation Modeling: Alternative Methode Use Partial Least Square). Semarang: BP Undip.

Giné, X. (2011). Access to capital in rural Thailand: An estimated model of formal vs. informal credit. Journal of Development Economics,96. (1), 16- 29.

Goacher, David, J. (1999). The monetary and financial system, published by financial world publishing.

Goran, A. Massara, A., \& Mialou, A. (2014). Assessing countries' financial inclusion- A new composite index. IMF .14-36

Gorton, G., \& Kahn, J. (2000). The design of bank loan contracts, Review of Financial Studies, 13, 331-364.

Hasler, A., \& Lusardi, A. (2017). The gender gap in financial literacy: A global perspective. Washington, DC: Global Financial Literacy Excellence Center, The George Washington University School of Business.

Haque, A. Zulfiqar, M. (2016). Women's economic empowerment through financial literacy, financial attitude and financial wellbeing. International Journal of Business and Social Science, 7, (3), 78-8.

Henseler, J. (2017). Bridging design and behavioral research with variance-based structural equation modeling. Journal of Advertising, 46, 178-192.

Henseler, J., Hubona, G. S., \& Ray, P. A. (2016). Using PLS path modeling in new technology research: Updated guidelines. Industrial Management \& Data Systems, 116, 1-19.

Henseler, J., Ringle, C. M., \& Sarstedt, M. (2016). Testing measurement invariance of composites using partial least squares. International Marketing Review, 33, 405-431.

Hung, A.J. Yoong., \& E. Brown (2012). Empowering women through financial awareness and education, OECD Working Papers on Finance, Insurance and Private Pensions, No. 14, OECD Publishing.

Islam, M S. (2014). Microcredit, financial inclusion and women empowerment Nexus in Bangladesh, Journal of Asian Development Studies, 3(2),7-15.

Jack, W., \& Suri, T. (2016). The Long-run Poverty and Gender impacts of Mobile Money. Science, 354 (6317), 1288:1292.

Joshi M. C. (2013). India: Literacy and women's empowerment, a tracer study in ASPBAE (2012) The power of literacy: women's journeys in India, Indonesia, Philippines and Papua New Guinea, Philippines: ASPBAE

Kabeer N. (1999). Resources, agency, achievements: reflections on the measurement of women's empowerment. Dev. Change 30 435-464. 10.1111/1467-7660.00125.

Kabeer N. (2005). Gender equality and women's empowerment: a critical analysis of the third millennium development goal. Gender and Development,13(1),13 - 24.

Karunathilaka, K. T. S. (2016). A Study on Financial Literacy of Rural Community in Sri Lanka: With Special Reference to Kurunegala District.17th Conference on Postgraduate Research, International Postgraduate Research Conference 2016, Faculty of Graduate Studies, University of Kelaniya, Sri Lanka.174.

Kumari D.A.T., Ferdous Azam S. M. (2019). The Mediating Effect of Financial Inclusion on Financial Literacy and Women's Economic Empowerment: A Study Among Rural Poor Women in Sri Lanka. International Journal of Scientific \& Technology Research, Vol 8, No 12, December 2019 ISSN 2277-8616. IJSTR@2019. www.ijstr.org.

Kumari D.A.T., Ferdous Azam S. M. \& Siti Khalida. (2020). The Impact of Financial Literacy on Women's Economic Empowerment in Developing Countries: A Study Among the Rural Poor Women in Sri Lanka. Journal of Asian Social Science; Vol. 16, No. 2, ISSN 1911-2017 E-ISSN 1911-2025.Published by Canadian Center of Science and Education.

Lusardi, A., \& Scheresberg, B. (2017). Financial capability and financial literacy among working women: New insights.Retrieved from http:/gflec.org/wp-content/uploads/2017/03/ Research-Report_WorkingWomen_March-2017.pdf?x87657

Madhubhashini Galagedarage, G. T. (2015). Issues in Internet Adoption and Rural Empowerment in Sri Lanka. Journal of Humanities \& Social Sciences, 9.

Mahdavi, Mahnaz. (2012). Financial literacy among educated women: Room for Improvement. Working Paper, Smith College.

Maheswari, M., \& Revathy, B. (2016). Empowering women: Uncovering financial inclusion barriers. Advances 
in Social Sciences Research Journal, 3(4), 9-29.

Mayoux, L. (2000). Microfinance and the empowerment of women: a review of the key issues, Social Finance Unit Working Paper, 23, ILO, Geneva

Mayoux, L., \& Hartl, M. (2009). Women's empowerment through sustainable microfinance: rethinking best practice.

Ringle, C. M., \& Sarstedt, M. (2016). Gain More Insight from Your PLS-SEM Results: The ImportancePerformance Map Analysis. Industrial Management \& Data Systems, 116(9), 1865-1886.

Ringle, C. M., Sarstedt, M., Mitchell, R., \& Gudergan, S. P. (2018). Partial Least Squares Structural Equation Modeling in HRM Research. The International Journal of Human Resource Management, forthcoming.

Ringle, C. M., Wende, S., \& Becker, J.-M. (2015). SmartPLS 3. Bönningstedt: SmartPLS. Retrieved from http://www.smartpls.com

Roy, B., \& Jain, R. (2018). A study on level of financial literacy among Indian women. IOSR Journal of Business and Management, 20(5), 19-24.

Prochaska, J.O. \& DiClemente C.C. Norcross JC (1992). In search of how people change. Applications to addictive behaviours. Am Psychol ,47-1102.

Prochaska, J.O. Velicer WF, Rossi J.S. (1994). Stages of change and decisional balance for 12 problem behaviours. Health Psychology 13, 39-46.

Ranieri, R., \& Raquel, A. (2013). Inclusive growth: Building up a concept. Working Paper 104. Brazil: International Policy Centre for Inclusive Growth. ISSN 1812-108X. Retrieved 13 January 2015.

Saha, B. (2016). A study of financial literacy of working women of Raipur city International Journal of Recent Trends in Engineering \& Research (IJRTER), 2, (11), 154-160. [ISSN: 2455-1457]

Salahuddin, K., \& Shamim, I. (1996). Rural women in poverty: NGO interventions for poverty alleviation, Dhaka: A Research and Study Group.

Sarstedt, M., Ringle, C. M., \& Hair, J. F. (2017). Partial Least Squares Structural Equation Modeling Handbook of Market Research,1-40, Springer.

Sarumathi, S., \& Mohan, K. (2011). Role of microfinance in women's empowerment: an impirical study in pendicherry region rural SHG's. Journal of Management and Science, 1(1) ISSN.

Satya R. Chakravarty., \& Rupayan Pal, (2010). Measuring financial inclusion: An axiomatic approach, Microeconomics working papers 22776, East Asian Bureau of economic research.

Savitha, B., \& Polepeddi, J. (2011). Financial access and woman empowerment, Research journal of social science and management, 1(6), 166-175.

Sekaran, U. (2000). Research Methods for Business: A Skill Building Approach (3rd Ed). New York: John Wiley \& Sons.

Sekaran, U. and Bougie, R. (2009). Research methods for business: a skill-building approach (5th ed.). Haddington: John Wiley \& Sons.

Sekaran, U., \& Bougie, R. (2014). Research methods for business: a skill-building approach (6th ed.). Haddington: John Wiley \& Sons.

Sekaran, U., \& Bougie, R. (2016). Research methods for business: a skill-building approach (7th ed.). Haddington: John Wiley \& Sons.

Schaner, Simone. (2016). The Persistent Power of Behavioral Change: Long-Run Impacts of Temporary Savings Subsidies for the Poor. Working Paper.

Scholtens, B., \& Wensveen, D. (2003). The theory of financial intermediation: An essay on what it does (not) explain SUERF studies - The European Money and Finance Forum, 2003.

Singh, C., \& Kumar, R. (2017). Financial literacy among women: Indian Scenario. Universal Journal of Accounting and Finance, 5(2), 46-53.

Thorat, A. (2006). Rural poor: Who are they and why? A Case Study of Madhya Pradesh, Journal of Social and Economic Development, Institute for Social and Economic Change, Bangalore, 8 (1), 41-67.

V. Mathivathani., \& Dr.M. Velumani (2014). Financial literacy among rural women in Tamilnadu, Indian Journal of Applied Research, 4 (12) ISSN - 2249-555X

Vithanagama R. (2016a). women's economic empowerment: A literature review. International Centre for Ethnic Studies(ICES),2, Kynsey Terrace, Colombo 08, Sri Lanka.

Vithanagama R. (2016b). Exploring Women's Empowerment. International Centre for Ethnic Studies(ICES),2, Kynsey Terrace, Colombo 08, Sri Lanka. 